\title{
Text Messages and the Detroit Mayor: Kwame Kilpatrick
}

\section{Tarana Hammond, USA}

\begin{abstract}
This content analysis examined how the Detroit Free Press and The Detroit News portrayed the text message situation of Mayor Kwame Kilpatrick in the eleven weeks immediately after the story broke in the news, identifying themes and portrayal. Hypothesis 4 was supported. The articles selected in this study illustrated negative portrayal of the mayor. The research could not depict a difference by the Detroit Free Press and The Detroit News in terms of there negative portrayal of the mayor.
\end{abstract}




\section{Introduction}

On January $24^{\text {th }} 2008$, the Detroit Free Press uncovered a story concerning the Mayor Kwame Kilpatrick and his Chief of Staff Christine Beatty allegedly the two had lied about their relationship during the police whistle-blower trial involving police officer, Gary Brown and mayoral bodyguard, Harold Nelthrope (Schaefer, 2008). Schaefer (2008) explained that the records which included several thousand text messages showed that the mayor and his chief of staff engaged in a romantic relationship and recalled their decision to fire Gary Brown. The false testimony potentially exposed them both to felony charges for perjury and misconduct (behavior) while serving as a public officer (Schaefer, 2008). As a result, this incident has been utilized as a case study to examine how the media portray situations that occur during an African American mayor's term in office.

\section{Purpose}

This content analysis examined how the Detroit Free Press and The Detroit News portrayed the text message situation of Mayor Kwame Kilpatrick. Moreover, this research explored how the Detroit media used various levels of negative portrayal in the news coverage about the text message situation.

\section{Rationale}

"Over the past 20 years there has been dramatic growth in the number of AfricanAmerican local elected officials. This growth has been particularly apparent in urban areas, with the most visible black officials being urban mayors. The difficulties in governing facing these mayors have been well documented and include dwindling jobs, white flight, poor schools, crime, and deteriorating housing. Some cities have had black mayors for more than 20 years, which should have reduced their novelty. If these mayors are still evaluated more in racial terms of performance, it is a negative conclusion for urban race relations (Howell \& McLean, 2001 p. 321- 322).”

Thus, this study was important to conduct because black mayors may not be portrayed in the media on their performance as mayors but, from a racial perspective when a controversial situation presents itself during their term in office. In particular it was important to identify how the two Detroit media (IV1 and IV2) portrayed Mayor Kilpatrick when the text message situation was presented during his term in office. Thus, there were two themes (IV3 and IV4) 
identified in this study which were racial and performance. Empirical research on black mayors have found various degrees of negativity while examining race and racism in elections of these mayors (Howell \& McLean, 2001), race-based voting in biracial mayoral contests (Browning \& Marshall, 1986), and white reaction to black candidates (Citrin, Green \& Sears, 1990). As such the researcher chose to exclusively examine various levels of negative portrayal.

The results yielded from this study will provide journalists with useful ways to portray African American politicians in the media when various types of situations present themselves during their terms in office. This study may also add to academic scholarship in the fields of journalism, political communication and politics.

The theoretical framework employed in this study was racial model and performance model. This study may also add to the body of knowledge on racial model and performance model.

Hence, this study may lend itself to initial explanations to why African American politicians are portrayed in a particular way when situations arise during their terms in office (Jasperson, Watts, Faber, \& Fan, 1998).

\section{Literature Review}

This literature review centered on the empirical research on black mayors, racial model, and performance model. First, this chapter explains the role of a mayor. Second, it discussed the empirical research on black mayors. Third, it provided an explanation of racial model. Fourth, it examined performance model. Last, this chapter discussed portrayal.

\section{Mayors}

A mayor is political elite. A mayor plays a critical role in the governance of cities and towns (Wolman, Page, Reavley, 1990). A mayor fulfills an important function by constituting one of the major routes of policy administration. Given the importance of the mayoralty, it is surprising what they do while in office, and what they do after they leave the position. Most research on elected public officials has identified characteristics such as education, class, and race. As a result, a plethora of research has been conducted on mayors such as voting choices (St.Dizier, 1978), misreporting and vicarious political participation (Volgy \& Schwarz, 2001) 
and the political life of black mayors (Jones, 1978). It is the latter that was of significance to this study.

\section{Empirical Research on Black Mayors}

The most publicized debate in our nation during the 1960s was that the government specifically city government lacked African American representation (Abney \& Hutcheson, 1981). Foster (1978) noted African Americans have been found to be less supported by and more alienated from the political system than whites. As a result of political outcry and empirical research there has been dramatic growth of African American representation in government especially city government (Abney \& Hutcheson, 1981; Gilliam \& Kaufmann, 1998; Howell \& McLean, 2001; Voss \& Lublin, 2001).

Black mayors have been seen as a novelty in politics (Howell \& McLean, 2001) which may explain why news coverage of mayoral election campaigns offers a fascinating illustration of how the concepts of race, racial difference, and racial division are constructed and perpetuated in our political discourse (Peer \& Ettema, 1998).

Thus, it is extremely important to identify how black mayors are being portrayed in the media, whether they are being framed from a racial perspective or solely on their performance. Consequently, an applicable way to theoretically guide this research on the media portrayal of Mayor Kilpatrick and his involvement in the text message situation during his term in office was to use the racial model.

\section{Racial Model}

Howell and McLean (2001) argue that the racial model is the most commonly used model in research on black candidates. Racial model assumes that voting for a black candidate in a biracial contest is based primarily on racial identity. There is ample evidence of race-based voting in biracial mayoral contests illustrating a strong correlation between race-based voting and racial identity.

A consequence of the racial model is that white citizen's evaluations of black mayors will be determined by their racial attitudes, that is, their level of racism (Howell \& McLean, 2001). Thus, the research on voting in mayoral elections clearly confirms the power of race, and 
there is certainly reason to expect that this model will extend and explain approval of the black mayor once he or she is in office. However, approval involves some subtle conceptual distinctions from voting.

When a citizen is asked whether or not he approves of a mayor, it is usually asks in terms of an evaluation of performance; that is voters are asked whether or not they approve of his or her handling of the job of mayor or his or her performance as mayor. This focuses attention on evaluations of performance as opposed to vote choice, which pits the mayor or mayoral candidates against another candidate.

In spite of this, race and/or racism may affect the performance measures themselves. That is, citizens' evaluations of conditions in the city, such as crime and employment prospects, may be affected by race. African Americans tend to have different perceptions across a variety of domains so it is reasonable to place race and racism theoretically antecedent to the performance model.

\section{Performance Model}

Empirical research on presidential approval typical utilizes the performance model to guide it. Performance model assumes that citizen's evaluations of conditions in the city and the mayor's perceived effectiveness in dealing with urban problems in regards to how well the mayor is doing his or her job and not based on race. Thus, performance is evaluated independently from race and/or racism.

Howell and McLean (2001) argued that performance matters in evaluating the black mayor. In spite of the significant racial polarization in mayoral approval, some citizens observe conditions in their city and give the mayor credit or blame. .

\section{Portrayal}

Portrayal refers to a depiction of an incident. Descriptive words are used to establish an accurate and detailed portrayal of the event and/or incident. Portrayal is usually measured in the following way: positive, negative, and neutral. For the purposes of this study the researcher examined the extent of negative portrayals. The researcher wanted to determine how negative the portrayal of Mayor Kilpatrick was in the two Detroit news outlets. For 
instance adjectives describing negative portrayal could include: corrupt, scandal, hiding, guilty, lies, cover-up, political battle etc.

\section{Research Question \& Hypotheses}

The literature yielded one research question and four hypotheses.

RQ: How did the Detroit Free Press and The Detroit News portray the text message situation of the Mayor Kwame Kilpatrick?

The Detroit Free Press uncovered the text message story and brought forth a lawsuit against the city to release the text messages (Detroit Free Press). As a result, the researcher hypothesized the following predictions:

H1: The Detroit Free Press will portray Mayor Kilpatrick more negatively than The Detroit News.

H2: The Detroit News will portray Mayor Kilpatrick more negatively than the Detroit Free Press.

Bledsoe, Combs, Sigelman, and Welch (1996) argued that race was the most distinctive feature of social and political life in Detroit. "Race affects where people live and how they see themselves and others. Race frames perceptions and influences many judgments (Bledsoe et al., 1996 p.508)." Racial tension has been a part of Detroit life for decades. Incidents like the Malice Green murder in 1993 have been magnified and made more salient by the Detroit media, which for example carried intense coverage of the trail of police officers.

H3: Racial articles will be more negative than performance articles.

H4: The Detroit News racial portrayal of the mayor is more negative than the Detroit Free Press performance portrayal of the mayor.

\section{Method}

This content analysis examined 80 news articles displayed on the front pages of The Detroit News and The Detroit Free Press on the text message situation of Mayor Kilpatrick from January 24, 2008 through March 31, 2008. Due to the high saturation of the situation in the media the researcher chose to examine this time period because the text message crisis began on January 24, 2008 and the Michigan Supreme Court decided on February 27, 2008 to refuse Mayor Kilpatrick's appeal to stop the release of the text messages being open to the public. In order, for the $2 \mathrm{X} 2$ factorial design to work appropriately the researcher chose to include 
articles after the Michigan Supreme Court hearing. By doing so, the media's portrayal has been illustrated more accurately and it assisted in the process of conducting several $t$-tests.

The unit of analysis for this study was the first paragraph of each news article. The assumption held was that the themes (racial and performance) of the articles were identified within the first paragraph. It is not assumed that the general public would read the entire article. The researcher chose to use stacks because electronic databases tend not to explain where the article was placed within the newspaper (Riff, Lacy, \& Fico, 2005).

The Detroit Free Press and The Detroit News together wrote over 300 articles however, for the purposes of this research, editorials, blogs, feature stories etc. were excluded from the sampling frame. Thus, the sampling frame consisted of a total of 253 news article that were derived from both newspapers (APPENDIX D).

The researcher has obtained a representative sample that was a random sample. The researcher utilized the sampling frame (APPENDIX D) to assist her in the selection process of content. After a random start every third article was selected of articles by conducting a systematic sample (Wimmer \& Dominick, 2003).

The independent variables used in this study were news outlets (The Detroit Free Press and The Detroit News) and themes (racial and performance). The dependent variable used in this study was portrayal specifically, the level of negative portrayal. Two trained coders were employed in this study to code 80 news articles written by The Detroit Free Press and The Detroit News. The researcher provided the following items to assist them in the training process a coding book, coding instructions, and coding sheets (APPENDICES A-C). The researcher has provided a table to illustrate the intercoder reliability between the two coders along with the full equation of intercoder reliability to calculate the Cohen kappa (APPENDIX E). The intercoder reliability was fair. The Cohen's kappa was 0.30.The statistical tests utilized in this study were frequencies, chi-square test, and $t$-tests.

\section{Results}

Eighty news articles were coded by two independent coders. Forty articles were written by The Detroit Free Press and forty articles The Detroit News. Figure 2 illustrates the raw data 
that was collected during this study. The numbers within each cell represents the level of negative portrayal of the text message situation for each article that was taken from the two newspapers.

Figure 2: $\underline{\text { News Outlets }}$

\section{The Detroit Free Press The Detroit News}

\section{THEME}

\begin{tabular}{|c|c|c|}
\hline$\underline{E}$ & 14 & 13 \\
\hline & 14 & 23 \\
\hline & 25 & 24 \\
\hline Racial & 25 & 24 \\
\hline$X$ & 25 & 35 \\
\hline & 35 & 35 \\
\hline & 35 & 35 \\
\hline & 35 & 3 \\
\hline Performance & 3 Cannot Identify & 35 \\
\hline $\mathrm{Y}$ & 3 Cannot Identify & 3 \\
\hline & 04 & 15 \\
\hline & 35 & 25 \\
\hline & 35 & 35 \\
\hline & 35 & 35 \\
\hline & 35 & 45 \\
\hline & 35 & 55 \\
\hline & 45 & 55 \\
\hline & 45 & 55 \\
\hline & 45 & 55 \\
\hline & 45 & $5 \quad 5$ \\
\hline & & Cannot Identify \\
\hline
\end{tabular}

A frequency test was used to answer the research question for this study. The data collected showed that both the Detroit Free Press and The Detroit News portrayed the text message situation involving the Mayor Kilpatrick in a negative way. To illustrate the findings graph 1 
through graph 4 were incorporated. The colors on the graph correspond to numbers ranging from 0 through 5 and cannot identify. These numbers represent the range of negativity. If further explanation is needed please refer to the coding book (APPENDIX A).

For the purposes of this study there was equal representation of both types of themes that were available for this research. Overwhelmingly, 97.5 percent of the articles from The Detroit News portrayed Mayor Kilpatrick in a negative way. The Detroit News used both a racial and a performance theme to cover the text message situation.

Graph 1: The Detroit News "Racial Theme"

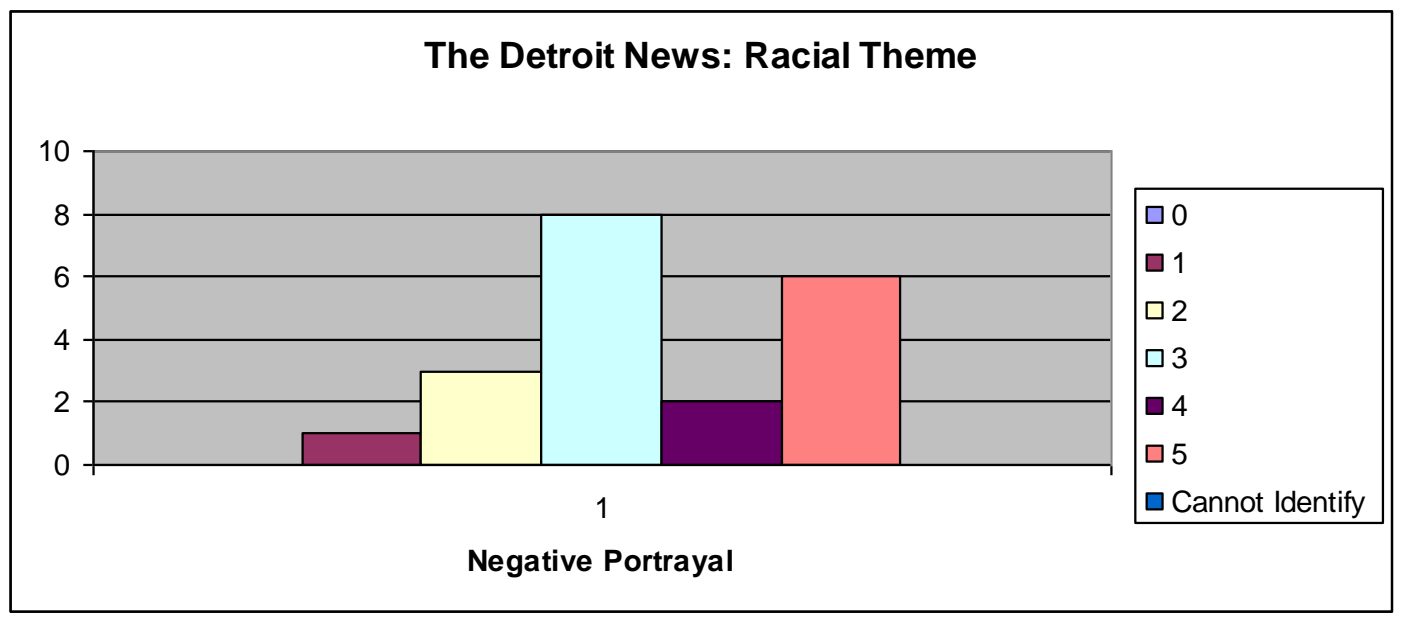

The Detroit News used various ranges of negativity to depict the text message situation involving Mayor Kilpatrick. Forty percent of the articles written by The Detroit News which used a racial theme used a moderate level of negativity. Thirty percent of the articles using a racial theme used an extreme level of negativity. Ten percent of the articles that used a racial theme used a high level of negativity. Fifteen percent of the articles used a low level of negativity. Last, only 5 percent of the articles used a very low level of negativity. 
Graph 2: The Detroit News "Performance Theme"

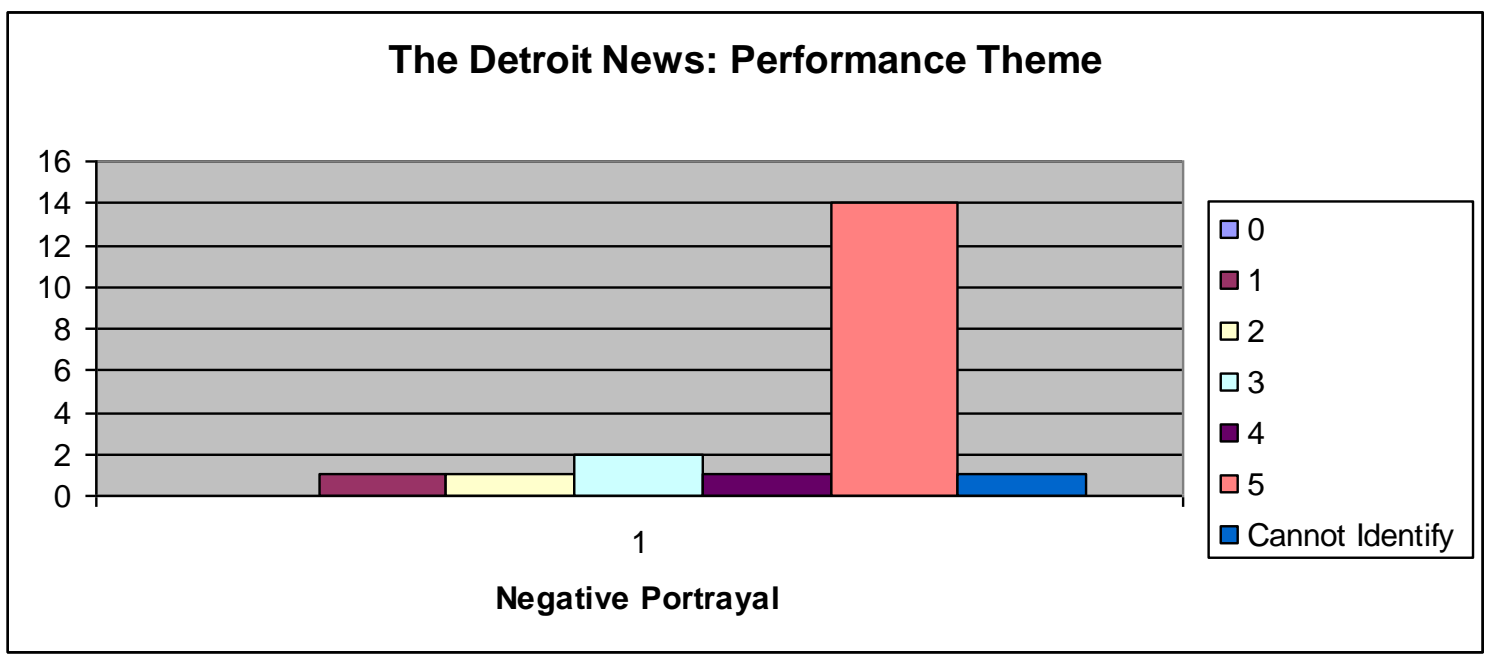

Seventy percent of The Detroit News articles that used a performance theme portrayed the mayor extremely negative in regards to the text message situation. Another ten percent of articles portrayed the mayor moderately negative. Five percent of the articles portrayed the mayor with very low negativity in regards to this situation.

Graph 3: Detroit Free Press "Racial Theme”

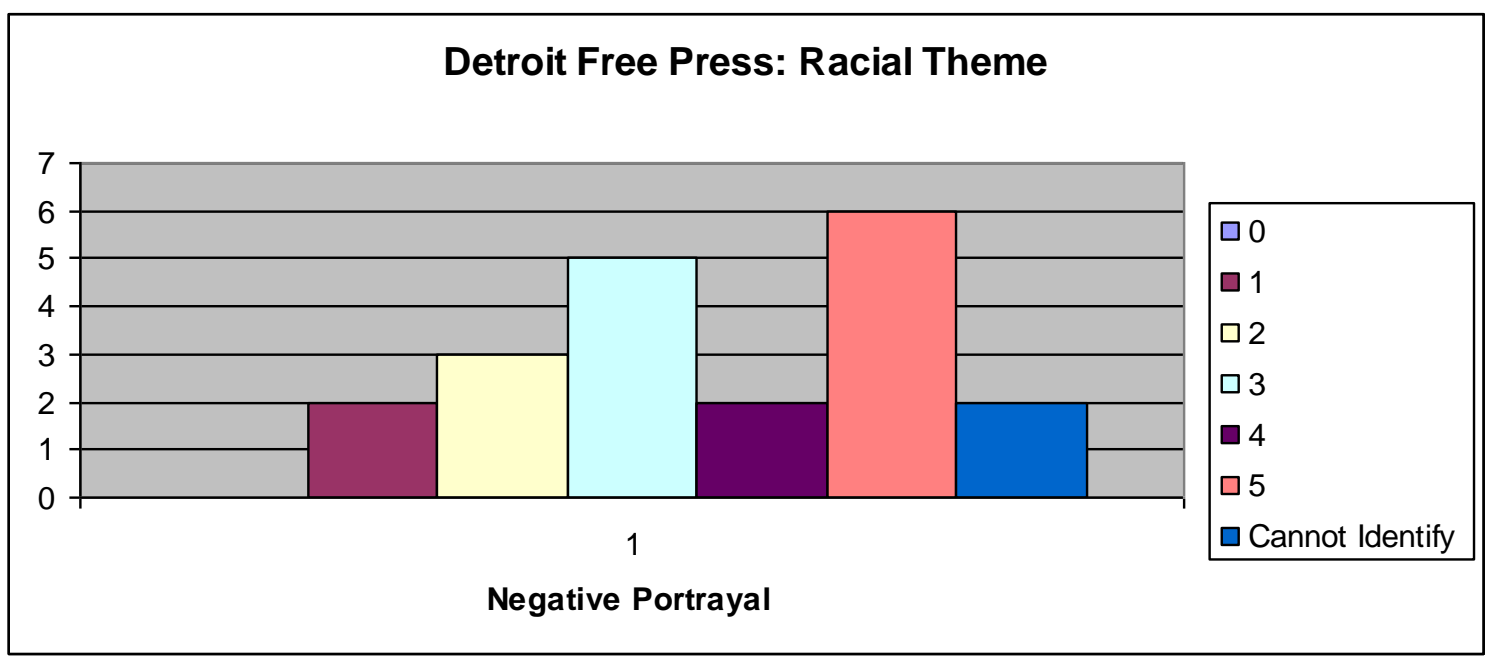

Thirty percent of the articles written by the Detroit Free Press portrayed the mayor extremely negative. Ten percent of the articles portrayed the mayor in a highly negative way. Twentyfive percent of the articles portrayed the mayor moderately negative. Fifteen percent of the articles portrayed the mayor by using a low amount of negativity. In addition, ten percent of the articles portrayed the mayor by using a very low amount of negativity during their coverage of the text message situation. 
Graph 4: Detroit Free Press "Performance Theme"

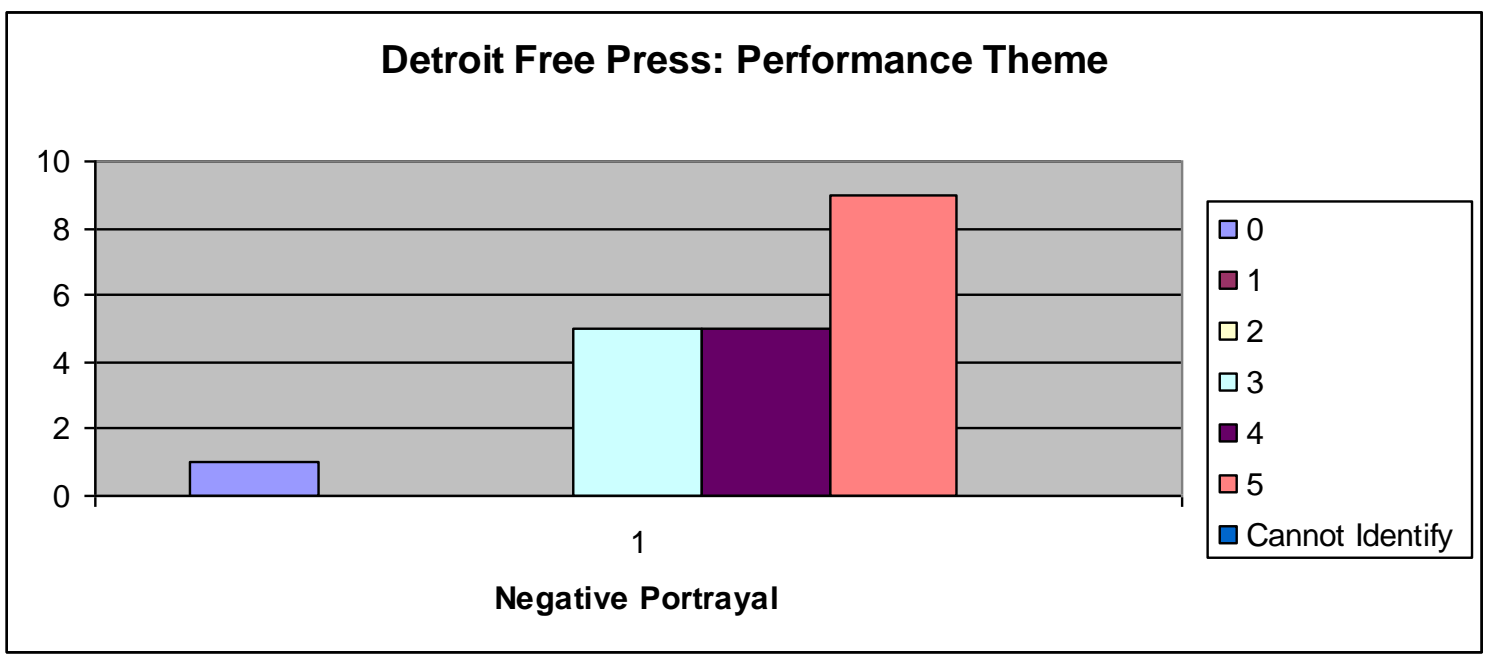

Forty-five percent of the articles using a performance theme which were written by the Detroit Free Press used extreme negativity in their portrayal of the mayor. While twenty-five percent of the articles portrayed the mayor highly negative. Yet, another twenty-five percent of the articles portrayed the mayor moderately negative. Last, five percent of the articles portrayed a very low amount of negativity toward the mayor in regards to the text message situation.

\section{Summary of Results}

To answer hypothesis one a $t$-test was conducted. The $t$-test was not greater than 1.67. As a result, hypothesis 1 was not supported by the data. Likewise, another $t$-test was conducted to answer hypothesis 2 .

The $t$-test was not greater than 1.67. As a result, hypothesis 2 was not supported by the data. That is logical because it suggests there is not a big enough variation between The Detroit News and the Detroit Free Press because they were both overwhelmingly negative. Therefore, the $t$-test fails to show significance and difference.

To answer hypothesis three another $t$-test was conducted. The $t$-test was not greater than 1.67. As a result, hypothesis 3 was not supported by the data. The reason why the hypothesis is not supported by the data is because there is not enough variation in the negative results. The Detroit News and the Detroit Free Press because they were both overwhelmingly negative. Therefore, the $t$-test fails to show significance and difference. 
However, hypothesis 4 was supported. The results from the $t$-test were greater than 1.684 which suggests that the findings were beyond chance. The results do not suggest that The Detroit News racially portray the mayor more negative than The Detroit Free Press portrayed performance. The researcher only conducted one chi-square test because there was only one hypothesis that was supported by the data. The chi-square test was conducted to examine if any correlations existed between The Detroit News negative racial portrayal of the mayor and the Detroit Free Press negative portrayal of Kilpatrick's performance as mayor. The chisquare test supported that there was not a relationship present $(r=-.18, p<0.05)$.

\section{Discussion \& Conclusion}

The data did not support hypothesis 1 , hypothesis 2, hypothesis 3, yet, hypothesis 4 was supported. Based on the results from the $t$ - test the researcher could not conclude an answer of significance for the first three hypotheses. However, for the fourth hypothesis the results were significant and not happened by chance. Therefore, the hypothesis was shown to be false.

With regard to the research question the vast majority of the articles selected are for the most part are not distinctive in their negative portrayal of the mayor. The research could not depict a difference by the Detroit Free Press and The Detroit News in terms of their negative portrayal of the mayor. However, while conducting the $t$-test for an interaction effect it was possible to determine that there was difference between in the portrayal of the mayor's performance in the Detroit Free Press and the portrayal of the mayor in the racial frames used by The Detroit News and that difference was more negative.

\section{Limitations}

There were several limitations in this study. The first limitation was the amount of coders. The second limitation was the number of articles. Thus, a scaling procedure could have been a beneficial to use when measuring negative portrayal. However, the limitations of this study made the scaling procedure too difficult to apply. The reason why was because there was variation among the coders when identifying if the article was racial or performance. Hence, a third coder would have been beneficial to this study. For instance, if the third coder had coded all articles for being performance or racial then the other two coders could have coded for negative portrayal which a scaling procedure could have been done. Hence, more coders would have improved the findings tremendously. Next, the coders themselves may have been bias in their perception of negative coverage on the mayor. Both of the coders are native 
Detroiters and African Americans thus, they may have perceived news coverage in a more sensitive way than someone who may not be a native of Detroit and/or African American. Last, limitation that challenged this study was the researcher's ability to conduct a chi-square correctly.

\section{Future Research}

Future research on black mayors should consider diversifying the type of coders recruited because interpretation of data can be greatly influenced. Also, try to ensure that there will be enough coders available to execute appropriate statistical tests. 


\section{Reference}

Abney, F. G., \& Hutcheson, J.D. (1981). Race, representation, and trust: Changes in attitudes after the election of a black mayor. Public Opinion Quarterly, 45, 91-101.

Babbie, E. (2007). The practice of social research. Belmont, CA: Thomson Wadsworth.

Bledsoe, T., Combs, M., Sigelman, L., \& Welch, S. (1996). Trends in racial attitudes in Detroit, 1968-1992. Urban Affairs Review, 31(4), 508-528.

Browning, R.P., \& Marshall, D.R. (1986). Black and Hispanic power in city politics: A forum. Political Science and Politics, 19, 573-640.

Citrin, J., Green, D., \& Sears, D.O. (1990). White reactions to black candidates: When does race matter? Public Opinion Quarterly, 54, 74-96.

Foster, L.S. (1978). Black perceptions of the mayor: An empirical test. Urban Affairs Quarterly, 14(2), 245-252.

Gilliam, F.D., \& Kaufmann, K.M. (1998). Is there an empowerment life cycle? Long-term black empowerment and its influence on voter participation. Urban Affairs Review, 33(6), 741-766.

Howell, S. E., \& McLean, W.P. (2001). Performance and race in evaluating minority mayors. Public Opinion Quarterly, 65, 321-343.

Jones, M.H. (1978). Black political empowerment in Atlanta: Myth and reality. The Annals of the American Academy, 439, 90-117.

Latimer, M.K. (1979). Black political representation in southern cities election systems and other causal variables. Urban Affairs Quarterly, 15(1), 65-86.

Peer, L., \& Ettema, J.S. (1998). The mayor's race: Campaign coverage and the discourse of race in America's three largest cities. Critical Studies in Mass Communication, $15,255-278$.

Philipsen, G. (1986). Mayor Daley's council speech: A cultural analysis. Quarterly Journal of Speech, 72, 247-260.

Riffe, D., Lacy, S., \& Fico, F. G. (2005). Analyzing media messages. London: Lawrence Erlbaum Associates, Publishers.

Schaefer, J. (2008, February 28). Full story now told of mayor's hidden deal. The Detroit Free Press. Retrieved March 5, 2008 from http://freep.com

St. Dizier, B. (1978). The effect of newspaper endorsements and party identification on voting choice. Journalism Quarterly, 589-594.

Volgy, T.J., \& Schwartz, J.E. (2001). Misreporting and vicarious political participation at 
the local level. Public Opinion Quarterly, 48, 757-765.

Voss, D. S., \& Lublin, D. (2001). Black incumbents, white districts: An appraisal of the 1996 congressional elections. American Politics Research, 29(2), 141-182.

Wimmer, R. D. \& Dominick, J. R. (2003). Mass Media Research an Introduction. California: Thomson Wadsworth.

Wolman, H., Page, E., \& Reavley, M. (1990). Mayors and mayoral careers. Urban Affairs Quarterly, 25(3), 500-514. 


\section{Appendices}
A. CODING BOOK
B. CODING INSTRUCTIONS
C. CODING SHEET
D. SAMPLING FRAME
E. INTERCODER RELIABILITY

\section{Appendix A}

\section{$\underline{\text { Coding Book }}$}

\section{PURPOSE}

a. This study examined new articles about the text message situation of Mayor Kwame Kilpatrick displayed on the front pages of The Detroit News and the Detroit Free Press from January 24, 2008 through March 31, 2008.

\section{UNIT OF ANALYSIS}

a. The unit of analysis for this study was the first paragraph of each news article.

\section{RULES FOR CODING DECISIONS}

a. News Outlets

i. Coders will code for the following new outlets: The Detroit News and the Detroit Free Press

ii. Coders will choose \#1 if the article comes from the Detroit Free Press

iii. Coders will choose \#2 if the article comes from The Detroit News

b. Theme

i. Coders will coder for the two themes: racial and performance.

ii. In order for the coders to code for the two themes definitions were provided.

1. Racial is based on the assumption that the mayor will be portrayed on the basis of his race rather than his role as mayor.

a. A keyword for identifying racial is racism.

b. Racism can be portrayed in the media as comments based on race and discrimination based on race. 
c. Black politicians will be less supported by and more alienated from the political systems than white politicians.

d. Coders will identify an article as racial if those involved in the text message situation are discussed about in regards of race instead of their performance in their positions.

e. An example of a racial themed article: "The heads of 17 Detroit municipal unions may ask Detroit Mayor Kwame Kilpatrick to resign or face recall effort, one of them said Thursday, following a Free Press report that Kilpatrick and his chief of staff lied under oath at a police whistle-blower trial last summer (The Detroit Free Press, January 25, 2008).”

f. The above example would be coded racial because lying under oath is not a clear reflection of Kilpatrick's duties, performance, and responsibilities as mayor.

2. Performance is when a citizen is asked whether or not he or she approves of the mayor. It is usually asked in terms of an evaluation of performance; that is, voters asked whether or not they approve of his or her handling of the job of mayor.

a. Performance focuses attention on evaluations of how well the functions (job duties, responsibilities of being a mayor) of the mayor are carried out.

b. An example of performance is provided below: Headline: "Contempt threats loom for city law chief, official" The city of Detroit's top lawyer and Mayor Kwame Kilpatrick's cousin a high ranking city official could be held in contempt of court for not cooperating with the Wayne County prosecutor's criminal investigation of the mayor and his former chief of staff."

c. This excerpt would be coded as performance because it discusses the attorney's job performance and how the 
attorney was not cooperating with Wayne County Prosecutor Kym Worthy. As a lawyer there are specific rules to releasing subpoena documents.

c. Portrayal

i. Coders will code for how the mayor was portrayed in both newspapers.

ii. Coders will code for the various levels of negative portrayal of the mayor. If coders cannot identify if the portrayal is negative the coders will code the article as "cannot identify."

iii. Negative portrayal refers to not positive or constructive criticism. Negative portrayal is a feature or aspect that is not positive or affirmative. Moreover, negative portrayal is a habitual attitude of skepticism or resistance to the suggestions or instructions of others.

iv. An example of negative portrayal is illustrated below: Headline "Memo kept council in the dark" Detroit's law department violated its legal duties when it urged the City Council to settle police whistle-blower lawsuits for $\$ 8.4$ million without disclosing the existence of damaging text messages, legal experts said Tuesday (Detroit Free Press).”

v. This expert is negative because the headline insinuates that the mayor and those working for the city were involved in concealing documents from the City Council. Moreover, this excerpt portrayals all involved in the cover-up in a negative way.

\section{PROVIDED EXAMPLE OF CODED TEXT}

a. Example of a news article

i. "Betty request to leave Detroit for job search rejected by magistrate" by Joe Swickard

ii. Article provided below: 


\section{Beatty request to leave Detroit for job search rejected by magistrate}

By JOE SWICKARD • Free Press Staff Writer • April 4, 2008

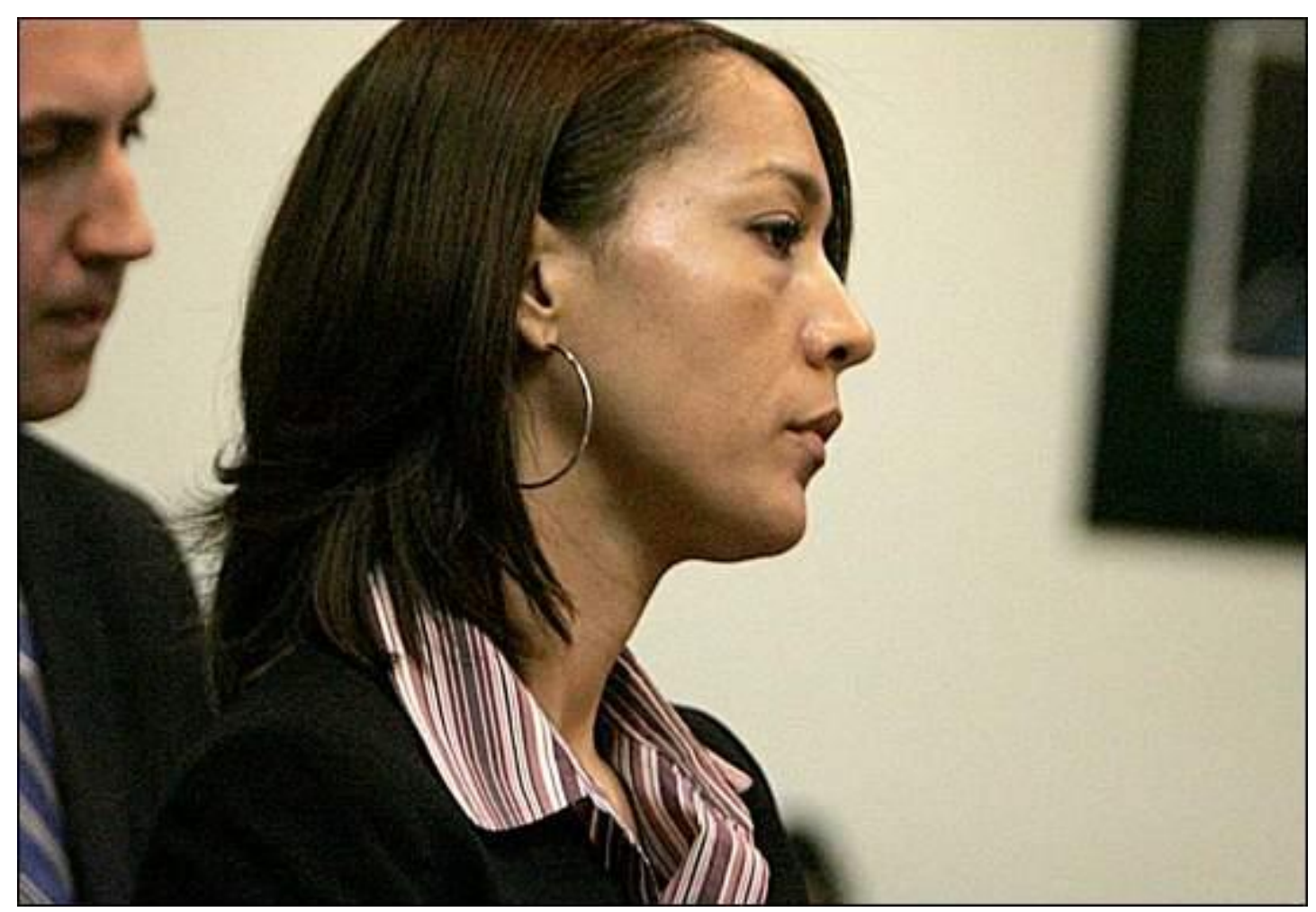

A Wayne County magistrate this afternoon rejected a request by Christine Beatty to modify the conditions of her bond release on perjury and other charges so she could leave Detroit to look for another job.

ADVERTISEMENT

The former chief of staff to Mayor Kwame Kilpatrick, who resigned her city position Feb. 8 in the wake of text message excerpts reported by the Free Press showing she and the mayor lied under oath about their affair, wanted to go visit her father in Alabama to look into job opportunities there and elsewhere, said her attorney, Mayer Morganroth.

But Magistrate Steve Lockhart refused to grant the request, insisting that Beatty had to have an interview for a specific job before he would permit her to leave the city under the terms of bond.

The courtroom in 36th District Court was closed to the media and the general public. A uniformed police officer told a Free Press reporter that the newspaper needed written authorization to enter the courtroom. Court rules normally require prior authorization for print photographers and camera crews to enter courtrooms. 
A Free Press reporter spoke briefly with Lockhart before the hearing in an effort to verify the proceeding and the magistrate indicated he did not speak to the media outside the courtroom and hung up. The Free Press raised objections about the closed proceeding with the state Supreme Court and the court administrator's office, which referred the inquiry to Lockhart and the office of President Judge Marilyn Atkins. Judge Atkins was not immediately available for comment.

Free Press attorney Herschel Fink called the closing of the courtroom to reporters "grossly improper" and a violation of the court's own rules, state law covering open court proceedings, and the Constitution.

"This is outrageous, absolutely outrageous," Fink said when he learned of the closure.

b. Example of coded sheet for article above

\section{CODING EXAMPLE}

Coding sheet for content of print coverage of the Mayor Kwame Kilpatrick Situation
A. Date of news article (month/day/year): ___ 4 /__ 4 _ _ _ 2008

B. Newspaper name: 1 = The Detroit Free Press;

2 = The Detroit News

C. Story identification number (Pay Close Attention) 01

D. Themes: $\_\_\underline{ } \_$1 = Racial

$2=$ Performance 3 = Cannot Identify

E. Portrayal: ㄴ_ 1 = Negative; 2 = Cannot Identify 
Negative is the type of portrayal being identified in this scale. 0 represents the absent of negative portrayal and 5 represents extreme negative portrayal. Please indicate the level of negative portrayal in this story from $0-5$. 3

\section{TRAINING EXERCEISE FOR CODER}

a. The coders for this study will examine the first paragraph of each news article on the text message crisis.

b. Each coder will code for the following variables: date, name of the newspaper, story identification number, placement of the news article, photos, frames, and tone.

c. After coders are trained they will participate in a pretest to for exclusivity and exhaustiveness.

d. The pretest will examine Associate Press coverage on the text message crisis.

VI. ROAD TEST: WHAT WENT WRONG?

a. The intercoder reliability was 0 . The kappa would be poor.

b. The researcher chose to refine her definitions and provide better examples.

\section{Appendix B}

\section{INSTRUCTIONS FOR NEWS ARTICLES}

Each story requires its own coding sheet. Write the story identification number beside the story. Each story should have a unique story identification number. Please keep coding sheets in the order of story identification number. Please remember that each unit of analysis must be placed within a category. Those categories are mutually exclusive and exhaustive therefore, a story can only be placed within one category. Remember that the headlines along with the first paragraph must be read by each coder.

A. Please write the date of news article in the space provided on the coding sheet. The date should appear at the top of the newspaper.

B. Please make a check mark in front of the appropriate line to indicate if the Detroit Free 
Press wrote the news article or if The Detroit News wrote the news article.

C. Please write the story identification number on the line provided. The identification number can be located in the top right hand corner of the news article. It should be apparent to you because every news article that is being coded in this study has a white sticker with a black number written inside the sticker on each article.

D. Please make a check mark in front of the appropriate line to indicate what theme the paragraph represents. The headline of the article and the first paragraph of the article will be coded. If the headline and the first paragraph of a news article discuss race and racism instead of performance will illustrate Mayor Kilpatrick in a less supportive way. If the paragraph illustrates this then it should be coded as racial (1). Please remember if a clear choice cannot be made after reading the first paragraph read further. Specifically, read the next paragraph to assist in the coding process. On the other hand if the first paragraph discusses the mayor and the text message situation in terms of his performance as mayor then mark the article as being performance (2). Please remember if a clear choice cannot be made after reading the first paragraph read further. Specifically, read the next paragraph to assist in the coding process. Last, if the first paragraph does not match any of the above themes then indicate that the theme cannot be identified (Please refer to the codebook for definitions of the themes).

E. A negative portrayal within a news article suggests that the news outlet is in favor of justice being served at the expense of those not abiding being sent to jail. So, if the first paragraph indicates that the mayor has lied and there is corruption within the city government that is a negative portrayal. As a coder you will read the first paragraph to determine how negative the article is on a scale of 0-5. 0 meaning absolutely no negative portrayal, 1 meaning very low negativity, 2 meaning low negativity, 3 meaning moderate negativity, 4 meaning high negativity and 5 meaning extreme negative portrayal. Please refer to the codebook for more examples of negative portrayal. Please remember if a clear choice cannot be made after reading the first paragraph read further. Specifically, read the next paragraph to assist in the coding process. 


\section{Appendix C}

\section{CODING SHEET}

Coding sheet for content of print coverage of the Mayor Kwame Kilpatrick Situation

A. Date of news article (month/day/year):

B. Newspaper name: $1=$ Detroit Free Press; $2=$ The Detroit News

C. Story identification number (Pay Close Attention)

D. Themes: $1=$ Racial 2 = Performance 3 = Cannot Identify

E. Portrayal: $1=$ Negative; $2=$ Cannot Identify

Negative is the type of tone being identified in this scale. 0 represents the absent of negative tone and 5 represents extreme negative tone. Please indicate the tone in this story from 0-5.

\section{Appendix D}

\section{$\underline{\text { SAMPLING FRAME }}$}

Detroit Free Press

1. SCANDAL MAKES A JOB TOUGHER

2. MOST TEXT MESSAGES JUST VANISH

3. 'I WOULD NEVER QUIT ON YOU. EVER': MAYOR: I'M SORRY

4. TEXT MESSAGE SCANDAL / MAYOR'S ATTORNEY TRAVELED TO SKYTEL

5. TEXT MESSAGE SCANDAL | MAYOR TO APOLOGIZE BUT WON'T QUIT JOB

6. TEXT MESSAGE SCANDAL: MAYOR'S SECRETS UNRAVELING

7. TEXT MESSAGE SCANDAL: MEMO KEPT COUNCIL IN THE DARK

8. TEXT MESSAGE SCANDAL | MAYOR'S SECRECY WRONG, COX SAYS

9. TEXT MESSAGE SCANDAL $\mid$ CITY'S TOP LAWYER ACKNOWLEDGES SETTLEMENT ROLE 
10. MAYOR HEADS TO HIGH COURT

11. WORTHY: A DECISION IN NEXT MONTH

12. BEATTY'S CITY EMPLOYMENT ENDS; NO SEVERANCE, PENSION

13. TEXT MESSAGE SCANDAL | MAYOR'S ATTORNEY TRAVELED TO SKYTEL

14. TEXT MESSAGE SCANDAL | MAYOR TO APOLOGIZE BUT WON'T QUIT JOB

15. MAYOR IS SEEN, BUT NOT HEARD

16. TODAY, SECRETS COULD EMERGE

17. TEXT MESSAGE SCANDAL: MAYOR'S TAKE ON PRIVACY DISPUTED

18. GOODMAN TO ADVISE PROBE OF MAYOR: COUNCIL'S PICK SEES TOUGH JOB

19. COURT PROBES EFFORT TO INFLUENCE APPEALS RULING

20. DTE CHIEF: MAYOR'S CREDIBILITY HURT

21. COUNCIL TO ASK COURT TO REJECT APPEAL

22. ETHICS BOARD TO STUDY COMPLAINT AGAINST MAYOR

23. COUNCIL SEEKS OUTSIDE LAWYER TO INTERVENE

24. TEXT MESSAGE SCANDAL | A WIDE RANGE OF REACTIONS: EX-COPS HOPE IT'S THE END; OTHERS FORGIVE MAYOR

25. DTE CHIEF: MAYOR'S CREDIBILITY HURT

26. COUNCIL TO ASK COURT TO REJECT APPEAL

27. ETHICS BOARD TO STUDY COMPLAINT AGAINST MAYOR

28. COUNCIL SEEKS OUTSIDE LAWYER TO INTERVENE

29. TEXT MESSAGE SCANDAL | A WIDE RANGE OF REACTIONS: EX-COPS HOPE IT'S THE END; OTHERS FORGIVE MAYOR

30. PROSECUTOR PROMISES A FULL INVESTIGATION

31. MAYOR PUSHES FOR JOBS, POLICE

32. RECALL PETITIONER'S EFFORT FACES TOUGH ROAD

33. TEXT MESSAGE SCANDAL | 4 HOURS OF TEXTING SOUGHT BY LAWYER FOR SLAIN STRIPPER'S SON

34. 'ANY ELECTRONIC COMMUNICATION' IS PUBLIC: MAYOR TEXTS DODGE CITY RULE

35. JUDGE TO CITY: WHY NOT SAVE STRIPPER MESSAGES?

36. TEXT MESSAGE SCANDAL | BEATTY QUITS

37. COURT PROCESS: CITY DOES NOT FILE APPEAL IMMEDIATELY 
38. TEXT MESSAGE SCANDAL | CITY FUNDS HELPED PAY FOR MAYOR'S RENDEZVOUS

39. TEXT MESSAGE SCANDAL | THE TESTIMONY FROM COPS' LAWYER

40. TEXT MESSAGE SCANDAL | THE KEYS TO THE COVER-UP | SUPREME COURT FREES THE LAST DOCUMENTS

41. LEGAL OBLIGATIONS: PENALTIES POSSIBLE FOR THE ATTORNEYS

42. WOMEN FACE DIFFERENT STANDARD IN SCANDALS

43. DETROIT'S TOP AUDITOR WARNS COUNCIL OVER INQUIRY POWER

44. JUDGE TO DECIDE FATE OF DOCUMENTS TODAY

45. TEXT MESSAGE SCANDAL | THE KEY EVENTS, PEOPLE AND RELATIONSHIPS \begin{tabular}{ll|lll|l|} 
46. TEXT MESSAGE SCANDAL & WAYNE COUNTY PROBE OF MAYOR
\end{tabular} INVESTIGATORS QUESTION COUNCIL MEMBERS

47. COX WADES INTO APPEAL

48. KILPATRICK REBOUND IS POSSIBLE, EXPERTS SAY

49. NEW SUBPOENAS PLANNED IN INVESTIGATION OF STRIPPER'S DEATH

50. REVIEWING MAYOR'S SPENDING: CITY'S QUIET AUDITOR THRUST INTO SPOTLIGHT

51. DEVELOPMENT: CITY GROWTH SHOULD GO ON, LEADERS SAY

52. LEADERSHIP IN TURMOIL: CITY UNIONS MAY SEEK MAYOR'S DEPARTURE

53. COUNCIL RIPS MAYOR IN COURT, BUT THEY'LL DO BUSINESS TODAY

54. SHOW SECRET FILES, APPEALS COURT SAYS

55. HARDWORKING BEATTY HAS REACHED CROSSROADS POINT

56. RELATIVES OF SLAIN STRIPPER WANT JUSTICE

57. WHAT HAPPENED SINCE THE VERDICT

58. ANOTHER DAY WITH NO RULING ON APPEAL

59. COUNCIL TO WEIGH OPTIONS TODAY FOR KILPATRICK PROBE

60. CONTEMPT THREATS LOOM FOR CITY LAW CITY, OFFICIAL

61. COUNCIL GAINS IN EFFORT T OBTAIN MORE INFO

62. MEMO KEPT COUNCIL IN THE DARK

63. DTE CHIEF: MAYOR'S CREDIBILITY HURT

64. COUNCIL DEMANDS MAYOR RESIGN

65. MAYOR WOULD ATTACK TEXT MESSAGES' AUTHENTICITY

66. COP GAVE BEATTY ADVICE IN FIRING 
67. BEATTY'S MOM: 'THIS BREAKS MY HEART'

68. WORTHY: 'WE'RE READY TO GO'

69. SHOWDOWN LOOMS AS SUPPORT FADES

70. COX SAYS KILPATRICK 'NOT FIT TO BE MAYOR'

71. BING TO MAYOR: CREDIBILITY SUFFERS

72. LET'S GET TO THE BOTTON OF THIS, SAYS COCKREL

73. A PLAN OF HOPE, A FLASH OF ANGER

74. DON'T BUY KILPATRICK'S TIRADE

75. MAYOR'S SPEECH TO DIVIDE COUNCIL

76. MAYOR'S PAL GOT INSIDE SCOOP ON CONTRACTS

77. BEATTY SHARED ADVICE, DETAILS OF BIDS FOR CITY PROJECTS

78. MAYOR'S FOE WANTS HELP FROM GRANHOLM

79. OLD FRIEND HELPS COP TAKE ON KILPATRICK

80. MYSTERY OF WHO KILLED STRIPPER THICKENS

81. CHIEF: DANCER PROBE HONEST

82. ATTORNEYS' CONDUCT QUESTIONED IN SCANDAL

83. THE MAN WHO SAYS KILPATRICK MUST GO

84. MAYOR REACHES OUT TP BUSINESS LEADERS, PASTORS

85. STRIPPER ACCUSED MAYOR'S WIFE SAYS EX-CLERK

86. MAYOR'S LAWYER NOT CHEAP, BUT KNOWN FOR RESULTS

87. MAYOR CHARGED

88. BEATTY QUITS

89. MAYOR'S ATTORNEY TRAVELED TO SKYTEL

90. MAYOR LIED UNDER OATH, TEXT MESSAGE SHOW

91. COUNCIL MEMBERS SEEK SEPARATE PROBE

92. LEADERSHIP IN TURNMOIL: CITY UNION MAY SEEK MAYOR'S DEPARTURE

93. EX-COPS' LAWYER TELLS OF SECRET PACT

94. HARDWORKING BEATTY HAS READHED CROSSROADS POINT

95. SLANDER SUIT: COPS WHO STOPPED BEATTY RETHINK

96. PROSECUTOR PROMISES A FULL INVESTIGATION

97. CITY UNION DISGUST WITH MAYOR GROWS

98. BEATTY OUT BUT NOT QUITTING, HER LAWYER SAYS

99. ADAMS RUNS CITY TEMPORARILY 
100. EX-COPS' LAWYER MUST TELL MORE ABOUT THE DEAL

101. CITY FUNDS HELPED PAY FOR MAYOR'S RENDEZVOUS

102. MAYOR: I'M SORRY

103. HEATED VIEWS CLASH ON THE COLD STREETS

104. SECRET DEAL'S DETAILS STAY SECRET FOR NOW

105. APOLOGY ACCEPTED, BUT BEHAVIOR ISN'T

106. APOLOGY IS TOO LITTLE, TOO LATE, CONSULTANTS SAY

107. MAYOR IS BACK, BUT NOT QUITE TO NORMAL

108. MAYOR WISHES BEATTY WELL, SAYS SCANDAL IS BLOW TO CITY

109. MESSAGES SOUGHT IN STRIPPER'S DEATH

110. KILPATRICK LOSES VOTER SUPPORT, POLL SHOWS

111. COUNCIL TO WEIGH OPTIONS TODAY FOR KILPATRICK PROBE

112. DETROIT'S TOP AUDITOR WARNS COUNCIL OVER INQUIRY POWER

113. WORTHY: RESIGNATION ALONE NOT ENOUGH TO SPARE MAYOR

114. WORTHY MAKES KILPATRICK THE FIRST DETROIT MAYOR TO FACE FELONY COUNTS

115. TEXT MESSAGE CASTS MORE DOUBT ON MAYOR

116. LEGAL PANEL INVESTIGATING LAWYERS IN MAYORAL SCANDAL

117. THE KEYS TO THE COVER-UP

118. RULING CALLED VICTORY FOR PUBLIC, COUNCIL

119. OWN UP, MR. MAYOR: WE KNOW THE TRUTH

120. MAYOR'S TAKE ON PRIVACY DISPUTED

121. MAYOR HEADS TO HIGH COURT

122. COUNCIL TO ASK COURT TO REJECT APPEAL

123. TODAY, SECREATS COULD EMERGE

124. MAYOR OK'D COVER-UP: KILPATRICK SIGNED THE PACT FOR SECRECY

125. COUNCIL SEEKS OUTSIDE LAWYER TO INTERVENE

126. MAYOR'S SECRECY WRONG, COX SAYS

127. CITY'S TOP LAWYER ACKNOWLEDGES SETTLEMENT ROLE

128. SHOW SECRET FILES, APPEALS COURT SAYS

129. WORTHY: A DECISION IN NEXT MONTH

130. KILPATRICK REBOUND IS POSSIBLE EXPERTS SAYS 
131. MAYOR TAKES DECISION ON APPEAL TO FINAL DAY

132. COUNCIL PANEL SEEKS MAYOR'S RESIGNATION

133. MAYOR IS SEEN, BUT NOT HEARD

134. MAYOR TO APOLOGIZE BUT WON'T QUIT JOB

135. MAYOR'S BUDDY NOW HIS RIGHT-HAND MAN

136. MAYOR: KILPATRICK DOESN'T PLAN TO QUIT

137. KILPATRICK: SOME SAY THE MAYOR;S SILENCE ISN'T GOLDEN

138. COUNCIL: RESOULTION SEEKS MAYOR'S RESIGNATION, BUT KILPATRICK SAYS AGAIN HE HAS NO PLANS TO QUIT

139. GRANHOLM: ACT QUICKLY TO RESOLVE SCANDAL

140. OUT AND ABOUT, MAYOR IS CHEERED

141. POLITICS: SCANDALS COULD COST KILPATRICK OUTSIDE OF DETROIT

142. MAYOR: SHOW SECRET FILES, APPEALS COURT AFFIRMS

143. WORTHY: PROSECUTOR PLANS DECISIONS WITHIN MONTH

144. RELATIVES OF SLAIN STRIPPER WANT JUSTICE

145. 4 HOURS OF TEXTING SOUGHT BY LAWYER SLAIN STRIPPER'S SON

146. SETTLEMENT: TOP LAWYERS HAD ROLE

147. MCPHAIL INSISTENCE PUZZLES 2 EX-COPS

148. COUNCIL: MOST BACK USING INDEPENDENT COUNSEL

149. JUDGE TO CITY: WHY NOT SAVE STRIPPER MESSAGES?

150. THE MAYOR'S STATEMENT: 'NO SECRET DEALS EXIST'

151. INVESTIGATORS QUESTION COUNCIL MEMBERS

152. IT'S NO BIG DEAL, KILPATRICK'S OFFICE SAYS OF NEW DISCLOSURE

153. EX-COPS HOPE IT'S THE END; OTHERS FORGIVE MAYOR

154. MOOD OF THE CITY: DETROITERS ARE CONFLICTED ABOUT MAYOR, POLL SHOWS

155. MAYOR'S SUPPORTERS PACK DETROIT CHRUCH

156. MAYOR CHARGE 


\section{The Detroit News}

157. Mayor, under fire, goes on offensive

158. Debate touches on Kilpatrick scandal

159. Texts propel dancer lawsuit into spotlight

160. Detroit Council delays vote on hiring attorney for text message case

161. Kilpatrick: Detroit needs 500 more cops

162. Kilpatrick: 'I am on an assignment from God'

163. Counsel: Suit deal ethical

164. Kilpatrick back at work

165. Mayor signed deal to hush up texting

166. City hall quiet as mayor's address nears

167. Secret documents that hid Kilpatrick texts released

168. Kilpatrick says he'll miss Beatty

169. Detroit mayor signed deal to cover up text messages

170. Words impress some local leaders

171. Prosecutor still weighing charges against Detroit mayor

172. Detroit Mayor Kilpatrick to break silence on text messaging scandal

173. Kilpatrick maintaining low profile today

174. Kilpatrick has other avenues in legal fight over text messages

175. Mayor ponders filing civil suit over text message leak

176. Secret documents that hid Kilpatrick texts released

177. 'It's bad for our image'

178. City lawyers' conduct examined

179. More legal action likely in Kilpatrick case

180. Kilpatrick's legal options running out

181. Mayor's nonprofit accounts difficult to track

182. Cops agreed to pay millions if they broke deal

183. Kilpatrick must go to help Detroit

184. Kilpatrick secret documents released

185. Kilpatrick secret documents due out today

186. Worthy investigation into Kilpatrick to last two more weeks

187. Kilpatrick goes to Capitol Hill to defend casinos 
188. Resolution calls on mayor, Beatty to testify before Detroit council

189. Forbid secret settlements with public money

190. Kilpatrick says he won't resign

191. Kilpatrick's legal options running out

192. Council president prepares to run Detroit

193. Detroit council members want to limit outside lawyer fees in mayoral scandal

194. Secret deal hid texts

195. Judge to weigh access to whistle-blower settlement documents

196. From meteoric to falling star

197. Mayor charged with 8 felonies: Mayor's attorney blasts case, outlines strategy

198. Mayor charged with 8 felonies: Beatty is also booked in high-profile case

199. Text shows mayor sought 'good answer' for cop firing

200. Mayor to get legal defense funding

201. Mayor bolsters legal defense team

202. Ex-clerk: Mayor's wife hit dance, report said

203. Council seeks to join suit for texts

204. Mayor sets agenda, calls out his critics: Kilpatrick cites 'illegal lynch-mob mentality'

205. Council scrutinizes mayor's spending

206. Cox: Mayor should quit

207. Court to look over more text messages

208. Council to mayor: resign

209. City’s whistle-blower legal tab: $\$ 845,282$

210. Worthy to reveal mayor probe result on Monday

211. Beatty perjury argued in'03

212. Petition for mayor's recall gets go-ahead

213. Council may audit mayor bills

214. Court ruling broadens terms for public

215. Council denied access to messages

216. Ethics panel takes up probes

217. Council demands settlement records

218. City hires lawyers to probe suit deal

219. Kilpatrick: Detroit needs 500 more cops 
220. Mayor signed deal to hush up texting

221. Court: release secret papers

222. Detroit council to vote again on adviser

223. Scandal tests mayo's survival skills

224. Mayor resumes public duties

225. Lawyer's threat led to secret deal

226. Council frustrated it didn't have all facts

227. Precedent set in 1994 applied to Kilpatrick case

228. Judge in papers' suit 'lives the law'

229. Mayor shamed by text messages

230. City exceeds legal-fee limit for Kilpatrick

231. Kilpatrick loses court fight; scrutiny grows: Secret records heat up probes by council prosecutor

232. Newly released papers show mayor tried to hide messages

233. Leaders wait for scandal to play out

234. Whistle-blower calls for mayor's resignation

235. Cops vent in 'Nightline'

236. Kilpatrick's memo set policy: Electronic messages are public

237. Mayor to break silence

238. New chief of staff's $1^{\text {st }}$ act: Pay his back property taxes

239. Beatty got biggest grant, even before mortgage program Ok'd

240. Secret deal hid texts

241. Worthy received call from mayor

242. Pressure builds as mayor, Beatty stay out of sight

243. Kilpatrick remains in seclusion

244. Mayor's aide quit as scandal unfolds

245. Out of sight, Kilpatrick huddles with advisers

246. Mayor scandal hurts Detroit

247. Beatty's future unclear

248. In digital age privacy is iffy

249. 'I'm sorry': He avoids discussing text messages, trial testimony

250. 'I'm sorry': Hurt, angry, disappointed but wife speaks up for him

251. Words impress some local leaders 
252. Strange day caps a strange week

253. Citizens question mayor's future

\section{Appendix E}

The table illustrates how the two coders coded the level of negative portrayal in the newspapers. The numbers (0-5) represent the levels of negative portrayal. All of the meanings for each number were provided in the coding book (APPENDIX A).

Table 4

Intercoder Reliability

\section{Coder 1}

\begin{tabular}{|c|c|c|c|c|c|c|c|}
\hline & 0 & 1 & 2 & 3 & 4 & 5 & \\
\hline Coder 2 & & & & & & \multicolumn{2}{|c|}{ Total: } \\
\hline 0 & & & & 2 & & 3 & 5 \\
\hline 1 & 1 & 2 & 1 & 1 & & & 5 \\
\hline 2 & & & & & 2 & 3 & 5 \\
\hline 3 & & & & 3 & & 1 & 4 \\
\hline 4 & & & & & 3 & & 3 \\
\hline 5 & & & & & & 8 & 8 \\
\hline & 1 & 2 & 1 & 6 & 5 & 15 & 30 \\
\hline
\end{tabular}

A: Calculate simple agreement, or the proportion of decisions both agreed on divided by the number of double-code units,

$$
\mathrm{N}: 8+2+3=13,13 / 30=0.433
$$

B: Calculate agreement by chance: Add the products of the marginal totals and divide by

$$
\begin{gathered}
\quad N^{2}:(1 \text { X 5 })+(2 \text { X 5) }+(1 \text { X 5 })+(6 \text { X 4) }+(5 \text { X3 })+(15 \text { X 8) / } 30 \text { X } 30 \\
N^{2}: 5+10+24+15+120 / 900 \\
N^{2}: 174 / 900=0.19 \\
\text { C. } \kappa=(\text { agreement })-(\text { agreement by chance }) / 1-(\text { agreement by chance }) \\
0.433-0.19 / 1-0.19=0.30
\end{gathered}
$$

